\title{
PERHITUNGAN NILAI CADANGAN PREMI MENGGUNAKAN METODE PREMIUM DIFFERENCE FORMULA DAN PAID-UP FORMULA
}

\author{
Nova Novianti, Neva Satyahadewi, Hendra Perdana
}

\begin{abstract}
INTISARI
Nasabah (tertanggung) yang sudah sepakat dengan perjanjian tertulis (polis asuransi) di perusahaan asuransi harus membayarkan premi. Perusahaan asuransi harus menyiapkan dana cadangan, hal ini memungkinkan perusahaan asuransi mendapatkan sumber dana baru untuk menutupi biaya tahun-tahun berikutnya dan mengantisipasi klaim yang akan terjadi pada saat nasabah meninggal dunia. Nilai cadangan asuransi dapat dihitung dengan cara prospektif. Perhitungan cadangan pada penelitian ini menggunakan metode premium difference formula dan metode paid-up formula pada produk asuransi jiwa dwiguna berjangka. Perhitungan metode premium difference formula menunjukkan bahwa cadangan merupakan nilai sekarang aktuaria dari selisih premi (premium difference) yang dibayarkan melebihi dari sisa pembayaran premi berjangkanya. Sementara itu, perhitungan metode paid-up formula diperoleh dengan memfaktorkan nilai sekarang aktuaria santunan yang akan datang dari rumus prospektif. Proses perhitungan nilai cadangan untuk ketiga metode diatas memiliki hasil yang sama dan memiliki perbedaan dalam informasi data. Pada masing-masing metode terdapat satu komponen didalam nilai cadangan yang tidak diketahui. Dalam menyelesaikan sebuah kasus harus diperhatikan setiap komponen yang ada pada masing-masing metode, misalnya pada metode prospektif tidak diketahui besarnya nilai premi bersih tahunan yang dibayarkan mulai tahun ke-t. Pada metode premium difference formula besarnya nilai sekarang aktuaria dari santunan tidak diketahui dan pada metode paid-up formula besarnya nilai anuitas awal tidak diketahui.
\end{abstract}

Kata Kunci: Cadangan prospektif, premium difference, dan paid-up

\section{PENDAHULUAN}

Salah satu risiko yang akan dialami oleh manusia adalah kematian. Risiko kematian akan terjadi kapan saja tanpa diketahui pasti. Apabila seseorang yang menghidupi suatu keluarga mengalami kematian, maka keluarga yang ditinggalkan tersebut dapat ditimpa oleh masalah ekonomi. Untuk mengatasi kejadian tersebut maka dibutuhkan sebuah perlindungan, salah satunya melindungi diri dengan mengasuransikan kematian dengan mengikuti asuransi jiwa. Asuransi jiwa adalah sebuah janji dari perusahaan asuransi (pihak penanggung) kepada nasabahnya (tertanggung) bahwa apabila nasabah mengalami risiko kematian dalam hidupnya, perusahaan asuransi akan memberikan santunan (manfaat kematian) dengan jumlah tertentu kepada ahli waris dari nasabah tersebut [1].

Pada saat mengikuti asuransi, nasabah berkewajiban membayar premi. Premi merupakan sejumlah uang yang wajib dibayar oleh pemegang polis kepada perusahaan asuransi dengan cara yang telah ditentukan dan sekaligus menjadi syarat diperolehnya perlindungan asuransi [2]. Produk asuransi jiwa yang memberikan dua manfaat adalah asuransi jiwa endowment (dwiguna). Asuransi jiwa dwiguna memberikan uang pertanggungan pada saat nasabah meninggal dunia maupun masih hidup pada saat berakhirnya masa pertanggungan. Perusahaan dalam mengantisipasi kerugian, maka sebagian dari premi yang diterima oleh perusahaan harus dicadangkan sebagai cadangan premi. Cadangan premi ini nantinya akan digunakan untuk membayar uang pertanggungan apabila terjadi klaim.

Salah satu metode yang dapat digunakan untuk menghitung nilai cadangan adalah metode prospektif. Metode prospektif adalah metode perhitungan cadangan dengan berdasarkan nilai sekarang dari semua pengeluaran pada waktu yang akan datang, dikurangi dengan nilai sekarang total 
pendapatan pada waktu yang akan datang untuk tiap pemegang polis. Bentuk lain dari metode prospektif yaitu metode premium difference formula dan paid-up formula. Metode difference formula merupakan metode yang memperlihatkan bahwa cadangan merupakan nilai sekarang aktuaria dari selisih premi (premium difference), sedangkan metode paid-up formula diperoleh dengan memfaktorkan nilai sekarang aktuaria santunan yang akan datang dari rumus prospektif. Metode paidup formula menunjukkan bahwa cadangan merupakan nilai sekarang aktuaria dari sebagian sisa manfaat yang akan datang.

Penelitian ini bertujuan untuk mengkaji dan menentukan nilai cadangan pada asuransi jiwa dwiguna menggunakan metode prospektif, premium difference formula dan paid-up formula. Perhitungan cadangan pada penelitian ini difokuskan pada produk asuransi jiwa dwiguna berjangka dengan menggunakan tabel kehidupan (life table) yang digunakan yaitu Tabel Mortalita Indonesia (TMI) tahun 2011. Langkah pertama dalam penelitian ini adalah menentukan asumsi-asumsi yang akan digunakan, yaitu usia nasabah, masa asuransi, Tabel Mortalita Indonesia (TMI) 2011 dan suku bunga. Selanjutnya diasumsikan pula besar uang pertanggungan untuk menentukan nilai sekarang aktuaria, nilai anuitas awal dan premi bersih. Langkah terakhir yaitu penentuan nilai cadangan menggunakan metode prospektif, premium difference formula dan paid-up formula.

\section{FUNGSI SURVIVAL}

Misalkan $X$ merupakan variabel random kontinu yang menyatakan usia hingga terjadinya kematian dari suatu kelahiran. Apabila $F_{x}(x)$ merupakan fungsi distribusi dari $X$ maka [1]:

$$
F_{x}(x)=\mathrm{P}(X \leq x) \quad, x \geq 0
$$

Peluang bahwa seseorang akan meninggal sebelum mencapai usia $x$. Kemudian selanjutnya didefinisikan fungsi survival, $s(x)$ sebagai sesuatu peluang yang menyatakan bahwa seseorang akan bertahan hidup mencapai usia $x$ yaitu [1]:

$$
s(x)=\mathrm{P}(X>x)=1-F_{x}(x)
$$

Apabila didefinisikan $x$ sebagai usia seseorang saat mengikuti produk asuransi jiwa maka sisa usia dari $x$, yaitu $X-x$ dapat dinotasikan dengan $T_{x}$. Notasi inilah yang selanjutnya akan digunakan dalam pernyataan-pernyataan berikut ini.

$$
\begin{aligned}
{ }_{t} p_{x} & =\operatorname{Pr}\left[T_{x}>t\right], \quad \mathrm{t} \geq 0 \\
{ }_{t} q_{x} & =1-{ }_{t} p_{x} \\
& =\operatorname{Pr}\left[T_{x} \leq t\right], \quad \mathrm{t} \geq 0
\end{aligned}
$$

Persamaan (3) dapat diartikan sebagai peluang untuk seseorang berusia $x$ akan tetap hidup hingga usia $x+t$. Sedangkan persamaan (4) dapat diartikan sebagai peluang untuk seseorang berusia $x$ akan meninggal sebelum mencapai usia $x+t$.

Berdasarkan Persamaan (2) dan (3) akan diperoleh:

$$
\begin{aligned}
& { }_{t} p_{x}=\frac{s(x+t)}{s(x)} \\
& { }_{t} q_{x}=\frac{s(x)-s(x+t)}{s(x)}
\end{aligned}
$$

\section{PREMI ASURANSI JIWA DWIGUNA}

Asuransi dwiguna (endowment) $n$ tahun dengan jumlah unit pembayaran pada akhir tahun kematian adalah kombinasi dari asuransi berjangka $\mathrm{n}$ tahun dan asuransi dwiguna murni (pure endowment) $n$ 
tahun. Hal ini berarti dalam maupun saat berakhirnya masa pertanggungan kepada pemegang polis, baik meninggal maupun bertahan hidup akan dibayarkan uang pertanggungan. Polis asuransi jiwa dwiguna menjanjikan pembayaran sejumlah uang bila terjadi kematian dalam jangka waktu atau bila tertanggung hidup diakhir jangka waktu [2].

$$
A_{x: n}=\left(\sum_{k=0}^{n-1} v^{k+1}{ }_{k} p_{x} q_{x+k}\right)+v_{n}^{n} p_{x}
$$

keterangan:

$A_{x: n} \quad$ : Asuransi jiwa dwiguna seorang berusia $x$ tahun dengan lama masa periode pertanggungan asuransi $n$ tahun

$n \quad$ : Lama masa periode pertanggungan asuransi

$k \quad$ : Sisa masa pertanggunganasuransi

$v^{k+1} \quad$ : Faktor diskonto periode $(k+1)$

${ }_{k} p_{x} \quad$ : Peluang seseorang berusia $\mathrm{x}$ tahun akan hidup sampai $\mathrm{k}$ tahun

$q_{x+k} \quad$ : Peluang seseorang berusia $(x+k)$ tahun akan meninggal 1 tahun ke depan

$v^{n} \quad$ : Faktor diskonto pada periode $\mathrm{n}$ tahun

${ }_{n} p_{x} \quad$ : Peluang seseorang berusia $x$ tahun akan hidup sampai $n$ tahun

Anuitas merupakan suatu pembayaran secara berkelanjutan dilakukan setiap selang waktu tertentu dengan besar uang yang sama. Anuitas jiwa adalah anuitas pasti dengan serangkaian pembayaran dalam interval waktu (pembayaran bulanan, empat bulan, tahunan) yang dilakukan selama seseorang masih hidup. Pada penelitian ini anuitas jiwa yang digunakan dalam perhitungan yaitu anuitas jiwa diskret awal berjangka $n$-tahun [2].

$$
\ddot{a}_{n}=\sum_{k=0}^{n-1} v_{k}^{k} p_{x}
$$

Premi merupakan sejumlah uang yang wajib dibayarkan oleh pemegang polis kepada perusahaan asuransi dengan cara yang telah ditentukan dan sekaligus menjadi syarat diperolehnya perlindungan asuransi [1]. Setiap orang yang mengasuransikan jiwanya, maka ia dikatakan telah menyetujui suatu kontrak secara tertulis antara dirinya dengan pihak perusahaan asuransi. Di dalam kontrak tersebut telah tertera besarnya premi yang harus dibayarkan beserta jadwal pembayarannya.

Premi dapat digolongkan menjadi dua yaitu premi bersih dan premi kotor. Premi bersih merupakan perhitungan premi tanpa memperlihatkan faktor biaya. Perhitungan premi bersih hanya menggunakan perkiraan tingkat suku bunga dan tingkat mortalita, sedangkan perkiraan tingkat biayanya tidak perlu digunakan. Premi kotor menambahkan biaya administrasi, gaji karyawan, komisi serta biaya-biaya operasional lainnya yang merupakan rahasia perusahaan sehingga besarnya turut diperhitungkan dalam penentuan tarif premi yang nantinya akan dibebankan kepada pemegang polis.

Pada penelitian ini menggunakan perhitungan premi bersih dengan jangka waktu pembayaran diskret. Bentuk diskret dari premi tahunan untuk asuransi jiwa dwiguna berjangka $n$-tahun [2].

$$
P\left(A_{x: n}\right)=\frac{A_{x: n}}{\ddot{a}_{x: n}}
$$

\section{TINGKAT SUKU BUNGA}

Tingkat suku bunga terdiri atas dua jenis, yaitu bunga tunggal dan bunga majemuk. Bunga tunggal atau sering disebut dengan bunga sederhana, dihitung berdasarkan pada perbandingan pokok dengan jangka waktu investasinya. Sedangkan bunga majemuk merupakan perhitungan bunga yang besar pokok dan jangka investasinya ialah jumlahan antara besar pokok sebelumnya dengan besar bunga yang diperoleh [4]. Tingkat suku bunga (i) adalah rasio dari besar bunga yang diperoleh selama 
periode tertentu terhadap besarnya nilai pokok pada saat awal periode. Nilai sekarang adalah investasi sebesar 1 yang akan terakumulasi menjadi $(i+1)$ pada akhir periode ke 1 . Nilai sekarang pada periode $n$ juga bisa disebut dengan faktor diskonto yang dinotasikan dengan $v^{n}$ [4], yaitu:

$$
v^{n}=\frac{1}{(i+1)^{n}}
$$

\section{CADANGAN PREMI}

Cadangan premi metode prospektif merupakan suatu metode yang melihat ke depan dalam waktu (perhitungan maju). Metode prospektif mendefinisikan cadangan sebagai selisih antara nilai sekarang aktuaria dari santunan yang akan datang dengan premi manfaat yang akan datang. Formula menghitung cadangan premi pada asuransi jiwa berjangka $n$-tahun menggunakan metode prospektif diskret sebagai berikut [2]:

$$
{ }_{t} V^{p}\left(A_{x: n}\right)=\left\{\begin{array}{cc}
A_{x+t: \overline{n-t}}-P\left(A_{x+n \cdot \overline{n-t}}\right) \ddot{a}_{x+t: \overline{n-t} \mid}, t \leq n \\
1 & , t=n
\end{array}\right.
$$

${ }_{t} V^{p}\left(A_{x: n}\right): \quad \begin{aligned} & \text { Nilai cadangan prospektif pada periode } t \text {, untuk asuransi jiwa dwiguna seorang } \\ & \text { berusia } x \text { dengan masa pertanggungan asuransi } n \text { tahun }\end{aligned}$ $A_{x+t: \overline{n-t}} \quad: \quad$ Nilai sekarang aktuaria seorang berusia $(x+t)$ yang mempunyai masa pertanggungan asuransi $(n-t)$ tahun

$P\left(A_{x+n: \overline{n-t}}\right)$ : Premi tahunan seorang berusia $(x+t)$ yang mempunyai masa pertanggungan asuransi $(n-t)$ tahun

$\ddot{a}_{x+t: \overline{n-t} \mid} \quad$ : Anuitas awal seorang berusia $(x+t)$ yang mempunyai masa pertanggungan asuransi $(n-t)$ tahun

Rumus cadangan premi dalam metode differensi (premium difference formula) diperoleh dengan memfaktorkan keluar nilai anuitas dari rumus prospektif sehingga nantinya akan diperoleh persamaan sebagai berikut:

$$
{ }_{t} V^{p d f}\left(A_{x: n}\right)=\left[P\left(A_{x+t: \overline{n-t}}\right)-P\left(A_{x: n}\right)\right] \ddot{a}_{x+t: \overline{n-t}}
$$

${ }_{t} V^{p d f}\left(A_{x: n}\right)$ : Nilai cadangan premium diffrence formula pada periode $t$, untuk asuransi jiwa dwiguna seorang berusia $x$ dengan masa pertanggungan asuransi $n$ tahun

$P\left(A_{x: n}\right) \quad: \quad \begin{aligned} & \text { Premi tahunan seorang berusia } x \text { tahun dengan masa pertanggungan asuransi } n \\ & \text { tahun }\end{aligned}$

Persamaan (12) memperlihatkan bahwa cadangan merupakan nilai sekarang aktuaria dari selisih premi (premium difference) yang dibayarkan melebihi dari sisa pembayaran premi berjangkanya. Selisih ini diperoleh dengan mengurangi premi tahunan awal dari besarnya premi asuransi pada saat tertanggung berusia $x+t$.

Rumus cadangan premi dengan metode paid-up formula diperoleh dengan memfaktorkan nilai sekarang aktuaria dari santunan yang akan datang dari rumus prospektifnya. Sehingga akan diperoleh:

$$
{ }_{t} V^{(p u)}\left(A_{x: \bar{n}}\right)=\left[1-\frac{P\left(A_{x: n}\right)}{P\left(A_{x+t: \overline{n-t}}\right)}\right] A_{x++t: \overline{n-t}}
$$

Persamaan (13) menunjukkan bahwa cadangan merupakan nilai sekarang aktuaria dari sebagian sisa manfaat yang akan datang.

\section{STUDI KASUS}

Sesuai dengan permasalahan yang dibahas dalam penelitian ini, yaitu menghitung nilai cadangan premi menggunakan metode premium difference formula dan paid-up formula, maka diberikan contoh 
kasus untuk menghitung cadangan premi pada asuransi jiwa dwiguna menggunakan metode premium difference formula dan paid-up formula. Dalam penyelesaian perhitungan akan dibantu dengan software Microsoft Excel dan Tabel Mortalita Indonesia (TMI).

Sebagai contoh kasus diberikan asumsi-asumsi sebagai berikut, usia tertanggung $(x), 25$ tahun, uang santunan $(B)$ Rp100.000.000, lama masa pertanggungan $(n), 10$ tahun, dan tingkat suku bunga (i), 5,75\%. Selanjutnya akan dicari nilai cadangan menggunakan Persamaan (11),( 12), (13). Berdasarkan perhitungan menggunakan bantuan Microsoft Excel diperoleh nilai cadangan dengan metode prospektif, premium difference formula dan paid-up formula.

Tabel 1 Perhitungan Nilai Cadangan

\begin{tabular}{|c|r|}
\hline Waktu $(\boldsymbol{t})$ & Nilai Cadangan \\
\hline 1 & $\mathrm{Rp} 7.247 .297$ \\
\hline 2 & $\mathrm{Rp} 14.912 .830$ \\
\hline 3 & $\mathrm{Rp} 23.006 .621$ \\
\hline 4 & $\mathrm{Rp} 31.571 .724$ \\
\hline 5 & $\mathrm{Rp} 40.636 .317$ \\
\hline 6 & $\mathrm{Rp} 50.230 .787$ \\
\hline 7 & $\mathrm{Rp} 60.386 .629$ \\
\hline 8 & $\mathrm{Rp} 71.137 .226$ \\
\hline 9 & $\mathrm{Rp} 82.517 .139$ \\
\hline 10 & $\mathrm{Rp} 100.517 .139$ \\
\hline
\end{tabular}

Jika perusahaan ingin mengetahui nilai cadangan pada tahun ke-2 untuk ketiga metode berdasarkan Tabel 1, maka diperoleh nilai cadangan yang harus disiapkan sebesar Rp14.912.830. Proses perhitungan nilai cadangan untuk kasus diatas dengan menggunakan metode prospektif, premium difference formula dan paid-up formula memiliki hasil yang sama dari tahun ke-1 hingga tahun ke-9. Pada tahun ke-10 perusahaan asuransi harus mencadangkan uang sebesar santunan yang telah dijanjikan yaitu Rp100.000.000.

Metode prospektif merupakan metode yang sering digunakan dalam menghitung nilai cadangan. Pada metode prospektif nilai premi tahunan tidak diketahui sehingga untuk menyelesaikan sebuah kasus harus melihat terlebih dahulu komponen yang terdapat pada metode prospektif. Metode prospektif dapat dikembangkan menjadi beberapa metode diantaranya metode premium difference formula dan paid-up formula. Metode premium difference formula dapat digunakan ketika nilai sekarang aktuaria tidak diketahui dalam kasus, kemudian kita dapat menggunakan metode paid-up formula ketika nilai anuitas tidak diketahui dalam kasus.

\section{PENUTUP}

Perhitungan cadangan premi menggunakan metode prospektif, premium difference formula dan paid-up formula mempunyai nilai cadangan premi yang sama dan memiliki perbedaan dalam informasi data. Pada masing-masing metode terdapat satu komponen yang tidak diketahui. Perhitungan nilai cadangan pada metode prospektif tidak diketahui besarnya premi tahunan seorang berusia $x$ tahun dengan masa pertanggungan asuransi $n$ tahun $P\left(A_{x: n}\right)$. Pada metode premium difference formula besarnya nilai sekarang aktuaria dari santunan $\left(A_{x+t: \overline{n-t}}\right)$ tidak diketahui selanjutnya pada metode paid-up formula besarnya nilai anuitas awal $\left(a_{x+t: \overline{n-t}}\right)$ tidak diketahui. Dalam menyelesaikan sebuah kasus menghitung nilai cadangan premi pada asuransi jiwa dwiguna berjangka 
untuk ketiga metode tersebut, kita harus menyesuaikan informasi data dengan metode yang akan digunakan.

\section{DAFTAR PUSTAKA}

[1]. Effendie, A. R. Matematika Aktuaria. Universitas Terbuka, Jakarta. 2010

[2]. Bowers, Newton L. Actuarial Mathematics, The Society Of Actuaries, Schaumburg, Illinois. 1997

[3]. Sembiring, R. K. Buku Materi Pokok Asuransi 1, Mod ke-1-5, Karunika, Universitas Terbuka, Jakarta. 1986

[4]. Futami, T., 1993. Matematika Asuransi Jiwa (Alih bahasa), Ed ke-2. Foundation, Jepang.

NOVA NOVIANTI

NEVA SATYAHADEWI

HENDRA PERDANA
: Jurusan Matematika FMIPA UNTAN, Pontianak nova.novianti1995@gmail.com

: Jurusan Matematika FMIPA UNTAN, Pontianak neva.satya@math.untan.ac.id

: Jurusan Matematika FMIPA UNTAN, Pontianak

hendra.perdana@math.untan.ac.id 